\title{
The identification of skills and competencies for effective management in social enterprises. A managerial perspective'
}

Martyna Wronka-Pośpiech, Ph.D. University of Economics in Katowice, Department of Entrepreneurship and Management Innovation

\section{Introduction}

Modern organisations operating in the turbulent environment are confronted with many complex requirements. This also applies to managers of social enterprises who face the challenge of implementing the mission combining social and economic goals (Muscat, Whitty 2009). The necessity to comply with external business requirements, the volatility of the environment and dynamic changes occurring in the third sector call for the presence of managers who will be able not only to deal with financial matters competently, but also use human resources optimally (Starnawska 2014; Barendsen and Gardner 2004, p. 48). What is more, the specificity of the third sector means entering into relationships with different groups of stakeholders, and managing these relationships plays a vital role in both legitimacy and accountability in delivering organisational objectives (Huybrechts et al. 2014, pp. 163-166). Nowadays social enterprises

1 The paper is financed under the project „Features and competencies of social entrepreneur research results"|"Cechy i kompetencje przedsiębiorcy społecznego - badania empiryczne". 
increasingly often execute activities typical of the business segment, becoming equal actors in the market game, competing for customers and resources with commercial enterprises. Furthermore, engaging in social entrepreneurship can also be challenging in terms of both personal and professional life - not only is there no permanent source of funding, no guarantee that a business idea will work in practice, or no stability, but also the boundary between work and private life blurs (Praszkier, Nowak 2012, p. 175).

All this translates into an increased interest in a person managing a social enterprise as the possibility of achieving organisational goals depends largely on people in charge. Mismanagement causes many problems, which in turn impinge on the organisational performance (Timmons 1999, pp. 536537). There is no doubt that a social enterprise should be run by a competent manager, preferably someone with a business track record and the in-depth knowledge of formal issues. It is also worth noting that both researchers and practitioners agree that proper leadership is crucial for the success of social enterprises (Sharir, Lerner 2006, pp. 12-14; Austen 2007, p. 54, Wronka 2009, pp. 113-115). Personality, charisma and leadership skills of a person managing a social enterprise are the drivers of the development of such an organisation. The aim of this paper is thus to identify and explore the key competencies and optimal features of a manager running a social enterprise. The hypothesis is that certain competences used by the management in social enterprises are specific to that sector. Data for this study was collected through a survey from 100 social enterprises in Poland.

\section{Characteristics of social enterprises}

Considerable discrepancies exist as to the meaning of a social enterprise. First of all, it combines the characteristics of a non-governmental organization and a market entity, creating new jobs and setting additional goals of sustaining these jobs and providing services to local communities (Leś 2004, p. 7). Based on the proposal included in the UK government document, a social enterprise can be defined as an institution that runs business activity, sets primarily social goals, reinvests the earned surplus for those purposes in the business or in the community, rather than being driven by the need to maximize profits for shareholders and owners (DTI 2002). R. Dart (2004, p. 415) argues that in order to fully understand the potential locked in social entrepreneurship, it is necessary to accurately define the concept of "a social enterprise". Generally, it is regarded as a basic institution of the social economy,

41

MARTYNA WRONKA-POŚPIECH 
a manifestation of new entrepreneurship, which pursues social obligations and is shaped by practices of the third sector. In the literature, some scholars perceive it as a more effective form of an organisation in the not-for-profit sector, while others include it in the for-profit sector, emphasizing at the same time that it caters to the social needs emerging in the market (Harding 2004, pp. 40-43). J. Pearce defines it as "all the economic entities that have a social objective, are not oriented towards the generation and distribution of capital, and have a democratic and measurable structure based on joint governance" (Pearce 2003, p. 190). H. Haugh (2006, p. 5) also sees a social enterprise as a collective term defining organisations acting for social objectives. They can adopt one of many available legal forms, but they share the commitment to finding solutions, based on commercial experiences, which will allow them to pursue social goals and reinvest profits from the operations with the benefit for the community. M. Yunus points out that social enterprises are organisations aiming to maximise social benefits for people, but they are not interested in making particular individuals (shareholders) rich (Yunus 2008). J. Thompson and B. Doherty (2006, p. 403) define them as organisations that apply business solutions to address social problems, while J. Hausner claims that they are part of the market economy that places their objectives and mission outside the market (Hausner et. al 2007).

Given the complexity of the phenomenon and the numerous interpretative disputes throughout the world, the EMES network provides nine guiding criteria. They are formulated in a relatively conservative way, which makes them more universal, but on the other hand limits their applicability and raises numerous interpretation-related concerns. The authors of the definition argue, however, that the criteria should not be regarded as necessary "conditions" that each organization has to fulfill to earn the label of the social enterprise, but they might rather serve as a description of "the ideal type" of such an enterprise (Defourny 2004, Defourny, Nyssens 2006, Defourny and Nyssens 2013). These are: continuous provision of goods or services, undertaking economic risk, hiring paid employees, clear goals oriented towards benefits of local community, bottom up initiative, high level of independence from other organizations, non-profit distribution, participative nature of the enterprise and decision-making not based on share in ownership (rule: one man-one vote). 
Table 1. Economic and social criteria that define social enterprises - EMES approach

\begin{tabular}{l|l}
\hline \multicolumn{1}{c|}{ Economic criteria } & \multicolumn{1}{c}{ Social criteria } \\
\hline $\begin{array}{l}\text { Continuous production activity of goods and/or } \\
\text { services }\end{array}$ & $\begin{array}{l}\text { An explicit goal dedicated to the benefit of the } \\
\text { community } \\
\text { A high degree of autonomy } \\
\text { A significant level of economic risk }\end{array}$ \\
A minimum number of employees & $\begin{array}{l}\text { Decision-making power not based on the principle of } \\
\text { capital ownership } \\
\text { Participatory nature, involving various parties affected } \\
\text { by the activity } \\
\text { Limited distribution of profit }\end{array}$ \\
\hline
\end{tabular}

Source: Defourny J., Nyssens, M. (2006), Defining social enterprise, in: M. Nyssens (ed.), Social Enterprise, Routledge, Abigndon, Oxon.

Basing on the work of members of "EMES", the European Research Network, some even say that in Europe researchers have reached a consensus regarding the definition of social enterprises being organisations active in the economic sphere (production of goods and services), that are the result of the initiative of citizens who are overtly motivated by a desire to bring benefit to the community, and regarding which the material interests of those who are providing the capital for the enterprises are limited (Defourny, Nyssens 2006).

Generally, the characteristic organisational forms that social enterprises adopt depend on the existing legal frameworks, on the political economy of welfare provision, and on both cultural and historical traditions of non-profit development in each country. As a consequence, the social enterprise sector nowadays may comprise both new typologies of organisations, as well as traditional third sector organisations (OECD 2003). Irrespective of the legal form, their principal purpose is not to generate commercial profit, but above all, to create workplaces for people at risk of social exclusion and professional marginalization (Sałustowicz 2007) and engage in delivery of social services and work integration services for disadvantaged groups and communities (WronkaPośpiech and Frączkiewicz-Wronka 2014).

Despite various legal forms and areas of operation, social enterprises share a number of features (Mair and Marti 2006, p. 38; OECD 2003, p. 27; Mason 2012, pp. 125-138):

- make a product or provide a service that involves business risk and it is verified in terms of the economic efficiency of this activity,

- are driven by social integration objectives on a scale of a given local community,

- give primacy to stakeholders' interests over shareholder relations, 
- their management culture is based on partnership and participation,

- democratic control comes from stakeholders,

- the earned surplus and accumulated capital are not owned individually, but they are used to pursue a particular social mission.

In Poland, in spite of 7 years of legislative effort, there has not been a social enterprise as a legal construct introduced into the system (Ciepielewska-Kowalik et al. 2014). However, basing on the nine guiding criteria by EMES, social cooperatives are closest to them when compared with other social enterprise models in Poland. According to the most recent data, there are about 1281 social cooperatives in Poland. What can be observed is a significant growth in their number as in 2009 there were 187 social cooperatives, in 2010 there were 276, in 2011 there were 402 social coops. This significant growth is a result of supporting social enterprises set up via public money, mainly European funds.

\section{Entrepreneurship competence and social entrepreneurship competence - literature review}

According to contingency theories developed by F.E. Fiedler (1967), R.J. House and T.R. Mitchell (1974), V.H. Vroom and P.W. Yetton (1973), and others, both leadership patterns and management style should be adapted to the specific organisational context (Schmid 2006). Therefore, it needs to be noted that the environment in which social enterprises operate entails specific challenges, opportunities, risks, and constraints with which a manager has to cope. On one hand, it is clear that social and commercial entrepreneurs and managers share some behaviours such as the ability to anticipate opportunities (Dearlove 2004; Dees 1998; Nicholls 2006; Peredo and McLean 2006; Roberts and Woods 2005); proactive behaviour toward survival, growth and serving the market (Mort et al. 2003; Prabhu 1999) or a willingness to bear risk (Peredo and McLean 2006). On the other hand, some key differences exist and have to be taken into consideration. For example, R. Martin and S. Osberg (2007) argue that when it comes to looking for specific distinctive features one should focus on a value proposition. While for a business entrepreneur achieving profit and seeking personal financial gain are essential, a manager operating in the third sector aims rather at solving social problems and creating social value. Although generating income is still important for the existence of the social enterprise, core activities shall remain focused on their social mission and creating impact. Also J. Boschee and J. McClurg (2003) identified two important ways in which a social entrepreneur differs from a traditional entrepreneur:

The identification of skills and competencies

for effective management in social enterprises. A managerial perspective 
- social entrepreneurs are driven by a double bottom line, a virtual blend of financial and social returns,

- profits are reinvested in the social mission.

There is also a matter of motivation to engage in social activities. For example, C. Cannon (2000) identified three categories of people who become engaged in social enterprises: (1) those who have financial resources and want to contribute to society, (2) "recovering social workers" seeking more efficient ways to do their work in the social sector, and (3) business school graduates with a social enterprise in mind. Some researchers argue that social entrepreneurs exhibit a socio-moral motivation for their entrepreneurial initiatives (Nicholls 2006, Shaw and Carter 2007). What is also pointed out by researchers are altruism, outrage and resentment at injustice (Dees 1998, Yujuico 2008) or compassion (Miller et al. 2012). M. Sharir and M. Lerner (2006) add to it personal rehabilitation, finding solutions to extreme situations at an individual level and fulfilment of obligations to the community by meeting local needs and problems. However, other authors claim that motivations of social entrepreneurs are similar to those of commercial entrepreneurs, being simply self-fulfilment, personal success and occupational independence (Hoogendoorn et al. 2010).

According to G.N. Prabhu (1999), our knowledge on social entrepreneurial leaders is inadequate, as no large sample studies exist which can be used for generalization and comparison. This point of view is still valid, as only few case accounts have the rich detail required to make adequate ideographic or content analytical studies. Although some exceptions exist - such as the GEM Report on Social Entrepreneurship (2011) or Schwab's Foundation report on Leadership in Social Enterprise (2014) - they focus mostly on leadership traits and characteristics of social entrepreneurs, namely, significant personal credibility, integrity and an ability to generate followers' commitment to the project by framing it in terms of important social values rather than purely economic terms (Borins 2000; Waddock and Post 1991).

Despite unquestionable ambiguities, existing empirical studies regarding, among others, leadership and organisational performance imply some similarities of activities undertaken by managers operating in the commercial, public and non-profit sectors. In the public sector, which bears a considerable resemblance to the social sector, K.W. Parry and S.B. Proctor-Thomson (2003) observed the impact of leadership on the performance and efficiency of public organisations. E. Thach and K.J. Thompson (2007), on the other hand, analysed 20 leadership competencies based on the interviews that they conducted with leaders working both in the for-profit and non-profit sectors. As a result, the 
competencies were ranked in a similar manner, with integrity, cooperation and stimulating the development of other people on top of the ranking. Therefore, it can be assumed that managers of social enterprises have similar features, skills and the ability to detect opportunities in the environment as managers working in the commercial or public sectors. What sets them apart, however, is the fact that they combine a profit strategy with a social mission, give employment to marginalised people or sell products or services having a direct impact on specific social problems. Some authors add to it that, in contrast to managers operating in for-profit sector, they are oriented towards achieving results in the long term (Kirby 2003, p. 20). This is in line with Thompson (2002), who claims that the set of competences necessary for commercial and social entrepreneurs are similar, but issues such as the social mission, the availability of funds from external donors, and previous experience and tacit knowledge create a basis for distinction between the two entrepreneurial types.

Empirical research regarding solely competences of social enterprises managers remains relatively scarce, yet it still provides the first step toward defining competences related to social entrepreneurship. One of the attempts has been undertaken by T.I. Miller, C.I. Wesley and D.E. Williams (2012, pp. 354$359)$, in the survey of whose respondents were asked to indicate the extent to which they believe a given competency is important to the education of social entrepreneurs. The results of the online survey directed to 150 respondents in the United States (CEOs, top managers, social entrepreneurs, founders, and social venture capitalists) show that the five competencies rated most important are: (1) the ability to problem-solve, (2) building effective teams, (3) management of financial capital, (4) the ability to lead and develop others, and (5) the ability to communicate with customers, suppliers, and other stakeholders. Another example is a study of Austrian social entrepreneurs (Hamzei 2011), which determined that opportunity, strategic, conceptual, organisational, networking, engagement, fundraising, mentoring and ethical competences are key competences for social entrepreneurs managing successful organisations (social ventures). Other existing research results point out to the ability to manage budgets and funds (Turner, Martin 2005), risk taking and networking (Thompson et al. 2000); teamwork and drive to innovate (Dees 1998b; Mair, Marti 2004); and perseverance (Prabhu 1999).

On the Polish ground, G. Urbanik-Papp and A. Krampus-Sepielak, came up with a proposition of a competence model for social entrepreneur (social manager) (Przedsiębiorczość społeczna... 2008, pp. 15-17). Interviews conducted with six managers of social enterprises proved that social and 
commercial entrepreneurs share behaviours corresponding to the classical model of the four functions performed by the manager (planning, organising, motivating and controlling). However, they perform managerial tasks in a specific manner, namely:

- putting emphasis on group activity and interpersonal relationships, which is usually associated with the democratic management style,

- showing great concern for external relations with important stakeholders and partners, which allows them to obtain contracts, grants and/or funds.

According to the authors' proposition, tasks performed by social entrepreneur are related to three main areas: (1) motivating a team, (2) entrepreneurship, and (3) managerial competences. The first area entails two behavioural competencies - supporting teamwork and motivating employees. While the latter refers to the interpersonal skills in contact with the group, the former involves contact with the individual employee. The second area is connected to entrepreneurial skills, while the third one concerns managerial skills and competences such as customer orientation, organisation and results orientation (Przedsiębiorczość społeczna... 2008, pp. 15-17).

\section{Methodology and research results}

In order to explore the key competences of a manager running a social enterprise, a modified questionnaire proposed by T.I. Miller, C.I. Wesley and D.E. Williams (2012) was used. Prior to the survey, the thorough examination of secondary data sources (foreign and domestic literature, published studies) was conducted in order to enrich the questionnaire proposed by the abovementioned authors. On this basis, the data collection instrument was created comprising statements related to potential competences. The questionnaire was used to collect data in the form of subjective opinions of respondents and was tested prior to the publication among managers of social enterprises as well as fellow scholars, in order to identify mistakes or ambiguity.

The target group in the survey were the representatives of top management (social entrepreneurs, managers managing social enterprises), who received the questionnaire directly, as variables used in the study require information to be provided by people who have the good knowledge of the functioning and development of the whole organisation. The respondents assessed a series of 35 statements, declaring the degree to which the statements accurately describe given situations. Responses are marked on a seven-point scale (ranging from 1, "important to a very little extent", to 7, "important to a very large extent"). 
The pilot study was conducted in social enterprises operating in the formula of social cooperatives based throughout Poland. The sample was selected randomly, comprised 100 social cooperatives and took place in the period from 1 December 2014 to 31 January 2015. The research indicates that on the Polish ground 10 out of 35 surveyed competences can be considered as critical. Table 2 displays the weighted averages, standard deviations and variances of the variables included in the study.

Table 2. Social Entrepreneurship (SE) competencies

\begin{tabular}{r|l|c|c|c}
\hline & & average & $\begin{array}{c}\text { standard } \\
\text { deviation }\end{array}$ & variance \\
\hline 1. & Creative use of minimal resources & 6.83 & 0.39 & 0.15 \\
\hline 2. & $\begin{array}{l}\text { Ability to relate/evaluate the feasibility of/ } \\
\text { implementation of business plan }\end{array}$ & 6.79 & 0.45 & 0.20 \\
\hline 3. & Conflict resolution skills & 6.79 & 0.53 & 0.28 \\
\hline 4. & $\begin{array}{l}\text { Ability to communicate with customers, suppliers, and } \\
\text { other stakeholders }\end{array}$ & 6.78 & 0.61 & 0.37 \\
\hline 5. & $\begin{array}{l}\text { Identification with the idea, actors and activities of the } \\
\text { social economy }\end{array}$ & 6.76 & 0.47 & 0.23 \\
\hline 6. & Confidence to succeed at challenging task & 6.75 & 0.787 & 0.17 \\
\hline 7. & Ability to manage administrative work & 6.71 & 0.914 & 0.41 \\
\hline 8. & Optimism & 6.71 & 0.64 & 0.538 \\
\hline 9. & Ability to identify social problems & 6.66 & 0.654 & 0.429 \\
\hline 10. & Ability to lead and develop others & 6.66 & 0.806 & 0.651 \\
\hline
\end{tabular}

Source: own study

The study helped to identify a hierarchy of competences necessary for social enterprise managers. The analysis of the overall evaluation of the distinct areas (calculated as the mean of each respondent's rating of the items in the areas) demonstrated that creative use of minimal resources was rated as the most important competence (mean 6.83, standard deviation 0.39). Organisations operating between the sectors, such as social enterprises, have various sources of financing, which inevitably is reflected in their strategy. Moreover, social 
enterprises have no guarantee that current source of funding will still be available in future. Therefore, managers need to be aware of diverse sources of financing and the possibility of obtaining grants from various sources (the state, foundations, companies, private sponsors etc.) and develop different scenarios in case of receiving or not receiving subsidies.

The second highest rated competence is the ability to create business plans and evaluate their feasibility (mean 6.79, standard deviation 0.45). It can be explained by the fact that the management has to be able to translate the mission into very tangible objectives, identify the scope of social enterprise activity and take into account the missions, objectives, and resources of the organisation as well as the tensions between the social aim and the economic requirements. Furthermore, it is necessary to seek global performance indicators specific to the social enterprise in order to evaluate the reach of very different goals.

The third rated competence is conflict resolution skills (mean 6.79, standard deviation 0.53 ). The choice of this factor stems directly from the fact that social enterprises nurture democratic governance based on the principle "one man, one vote". This can lead to conflict especially in an emergency situation, when decisions have to be made quickly and efficiently, bypassing the democratic decision-making process. The ability to resolve conflicts is also crucial for the proper functioning of a social enterprise, as when conflict arises employees no longer create a well-functioning organisation.

Another competence identified by respondents is the ability to communicate with customers, suppliers, and other stakeholders (mean 6.78, standard deviation 0.61). An important element determining effective functioning of a social enterprise is the ability to work with business partners and other organisations, such as public sector organizations, the business sector, socially responsible organisations, and other social economy entities. Stakeholder relationship management is a difficult task as stakeholders often have goals, which can sometimes even seem contrary to goals of social enterprise. Therefore, the manager needs to try to reconcile different stakeholder expectations and solve emerging problems in this field.

According to the respondents, the fifth competence is identification with the idea, actors and activities of the social economy (mean 6.76, standard deviation 0.47). Managers of a social enterprise should know, understand, and position the social economy within its general context (e.g. in relation to the market, the public sector, the possible competitors, etc.). Moreover, they need to understand different concepts, particular to social enterprises, such as the non-profit, social economy, social enterprise, third sector, etc., as well as to understand the 
legal environment surrounding social enterprises (such as legal forms a social enterprise can have and their strategic advantages). It also seems necessary to be familiar with public regulations (specific legal constraints, public policies, public revenue sources, etc.).

Another competence identified by the respondents is the confidence to succeed at challenging task (mean 6.75, standard deviation 0.787). This is connected with the fact that a social entrepreneur - by recognizing and exploiting opportunity in the environment - creates social value. This opportunity often has the form of an obvious or not so obvious social problem or an unmet social need, and sticking with it requires consistency and perseverance.

The choice of the seventh factor, the ability to manage administrative work (average 6.66, standard deviation 0.806), can be explained by the fact that, similarly to managers operating in the commercial sector, social entrepreneurs must also plan, motivate, organise, make decisions, delegate, coordinate, report, supervise and manage finance. No matter how meaningful the objective of a social enterprise, one must not forget about the mundane reality.

The respondents also expressed a strong belief in the importance of optimism in the activities of social enterprise managers (average 6.71, standard deviation 0.64). It is not, however, about being too optimistic, failing to notice risk or making dodgy decisions, but rather about optimism, ambition and perseverance in the fight against social problems and promoting innovation on a large scale. As Cristobal Colon, founder of La Fageda2, notices even the craziest business can succeed if its founders are completely committed to it and confident of ideas they wish to pursue.

The ninth competence identified as crucial by the respondents is the ability to identify social problems (average 6.66, standard deviation 0.654). This is connected with the scope of activity of social enterprises and social innovations being often subject of its activities. The latter is defined as a novel solution to a social problem that is more effective, efficient, sustainable, or just, than the existing solutions.

The choice of the tenth factor (average 6.66, standard deviation 0.806) can be explained by the fact that for the proper functioning of social enterprises a strong leader is necessary regarded as a change agent who supports the changes, stresses and implements them, and is involved in conducting and coordinating the project. At the same time, he is characterised by high motivation, relevant skills and the ability to inspire others.

2 La Fageda is a famous Catalan cooperative giving jobs to people with mental disabilities. 


\section{Conclusions}

The current situation requires that social enterprises are innovative and their orientation needs to be modified towards organisations achieving results in terms of efficiency and effectiveness (Kieżun 2000, p. 32). The shift in viewing entrepreneurship has been noticeable recently. Entrepreneurship is not only an economic but also a social activity that influences society (Steyart and Katz 2004, p. 82) and positive outcomes are not the necessary condition of entrepreneurship (Shane 2003, p. 57, Dey and Steyaert 2010, p. 89-93). The Polish non-profit sector is at the growth stage, with more and more attention given to hybrid forms such as social enterprises. Therefore, exploring the key competencies and optimal features of a manager running a social enterprise is fundamental as the success of any organisation depends largely on who manages it.

The presented results do not show a large discrepancy in relation to the results of similar studies conducted in the United States - the main difference that remains is actually in terminology. Other differences can be - to some extent - explained by the ambiguous nature of social enterprises and major differences between countries. A major limitation of the study is the very specific target group, identified by using the theoretical EMES criteria for social entrepreneurship (social cooperatives, being the closest to EMES criteria when compared with other social enterprise models in Poland). The focus on Poland and a relatively small sample, being a result of the fact that this paper presents the results of the pilot study only, may also be considered limitations. On the other hand, the study makes several valuable research contributions. Firstly, it approaches the concept of social entrepreneurship through a competence perspective. Approaching social entrepreneurship from the competence view makes it possible to incorporate this topic into educational programmes to help foster the growth in social entrepreneurship. Research results also encourage the further improvement of the data collection instrument and bring into focus the theoretical development of the subject in the future research. Moreover, this study is the first quantitative approach to social entrepreneurship on an individual level in Poland, in terms of individual antecedents. As Davister (2010) argues, the formalisation of practices of human resources management seems essential for the future development of the social enterprise sector. Therefore, there is still much to be done in the field of social enterprise management. 


\section{Summary}

The identification of skills and competencies for effective management in social enterprises. A managerial perspective

The need to adapt to external business requirements, turbulences present in the environment as well as the dynamic changes occurring in the non-profit sector require the presence of managers who are not only capable of taking proper care of financial issues, but also of optimally deploying available human resources. Today, organisations operate in the world without fixed rules of conduct or a universal management style. As a consequence, there is no universal recipe for success. It is, however, clear that the social enterprise should be run by a competent manager, preferably someone with a business track record and in-depth knowledge of formal issues. The literature review shows that working in a social enterprise requires a high degree of flexibility, a variety of skills and qualifications with the management facing a difficult challenge of how to simultaneously achieve social and economic objectives. The purpose of this article is to identify and explore the key competences and optimal features of the social enterprise manager. Data for the study was collected through a survey from 100 social enterprises in Poland.

Keywords: social entrepreneurship, social enterprise manager, competencies, leadership, social enterprise, social economy.

\section{Streszczenie}

Cechy i kompetencje $w$ zarządzaniu przedsiębiorstwem społecznym. Perspektywa menedżerska

Konieczność dostosowywania się do zewnętrznych wymagań biznesowych oraz turbulentność otoczenia, jak również dynamiczne zmiany zachodzące $\mathrm{w}$ sektorze non profit wymagają obecności menadżerów, którzy nie tylko będą potrafili zabezpieczyć kwestie finansowe, ale także wykorzystywać zasoby ludzkie w optymalny sposób. Organizacje funkcjonują dziś w świecie, który nie ma stałych regul, który nie posiada uniwersalnego stylu zarządzania, a co się z tym wiąże nie ma również uniwersalnej recepty na sukces. Wiadomym jest jednak, że konieczne jest, aby na czele przedsiębiorstwa społecznego stał kompetentny menadżer,

The identification of skills and competencies

for effective management in social enterprises. A managerial perspective 
najlepiej ktoś $\mathrm{z}$ praktyką $\mathrm{W}$ przedsiębiorstwie sensu stricto biznesowym i potrafiący sobie radzić z kwestiami formalnymi. Analiza literatury wskazuje bowiem, że praca w przedsiębiorstwie społecznym wymaga dużej elastyczności, różnorodnych umiejętności i kwalifikacji, a zarządzający stoją przed trudnym wyzwaniem jakim jest równoczesna realizacja celów społecznych i finansowych. Celem niniejszego artykułu jest zbadanie i określenie najbardziej optymalnych cech i kompetencji kluczowych dla pracy zarządzającego przedsiębiorstwem społecznym. Badania zostały zrealizowane za pomocą kwestionariusza ankiety w 220 przedsiębiorstwach społecznych na terenie Polski.

\section{Słowa}

kluczowe: przedsiębiorczośćspołeczna, zarzadzający przedsiębiorstwem spotecznym, kompetencje, przywództwo, przedsiębiorstwo społeczne, ekonomia spoteczna.

\section{References}

1. Austen A. (2007), Nowe trendy w ekonomii i zarzadzaniu. Znaczenie koncepcji sieci dla rozwoju przedsiębiorczości społecznej, "Problemy Zarządzania", No. 3 (17), pp. 50-62.

2. Barendsen L., Gardner H. (2004), Is the Social Entrepreneur a New Type of Leader? "Leader to Leader", Vol. 34, pp. 43-50.

3. Borins S. (2000), Loose cannons and rule breakers, or enterprising leaders? Some evidence about innovative public managers, "Public Administration Review", Vol. 60, pp. 498-507.

4. Boschee J., McClurg J., (2003), Toward a Better Understanding of Social Entrepreneurship: Some Important Directions, (online) http://senscot.org/ networks1st/downloads/publications/Toward \% 20a \% 20better $\% 20$ understand ing\%20of\%20social\%20entrepreneurship.pdf (accessed 20.4.2015).

5. Cannon, C. (2000), Charity for profit: how the new social entrepreneurs are creating good by sharing wealth, "National Journal", 16 June, pp.1898-1904.

6. Ciepielewska-Kowalik A., Pieliński B., Starnawska M., Szymańska A. (2015), Looking for Social Enterprise Models in Poland: Institutional and Historical Context, ICSEM Working Papers, No. 2015-11, Liege: The International Comparative Social Enterprise Models (ICSEM) Project, 1-39. 
7. Dart R. (2004), The legitimacy of social enterprise, "NonProfit Management \& Leadership", No. 14 (4), pp. 411-424.

8. Dearlove D. (2004), Interview: Jeff Skoll, "Business Strategy Review", Vol. 15, No. 2, pp. 51-53.

9. Dees G. (1998a), Enterprising non-profits, "Harvard Business Review", Vol. 76, No. 1, pp. 54-56.

10. Dees G. (1998b), The Meaning of 'Social Entrepreneurship', Kauffman Centre for Entrepreneurial Leadership (online) http://www.caseatduke.org/ documents/dees_sedef.pdf (accessed 3.5.2015).

11. Defourny J. (2004), Introduction: from third sector to social enterprise, [in:] C. Borzaga, J. Defourny (eds.), The Emergence of Social Enterprises, Routledge, London.

12. Defourny J., Nyssens M. (2013), Social Coops: When Social Enterprises meet the Cooperative tradition, paper presented at 4th EMES International Research Conference on Social Enterprises, July, Liege, Belgium, 1-4 July 2013.

13. Defourny J., Nyssens, M. (2006), Defining social enterprise, [in:] M. Nyssens (ed.), Social Enterprise, Routledge, Abigndon, Oxon.

14. Fiedler F.E. (ed.) (1967), A Theory of Leadership Effectiveness, John Wiley and Sons, New York, NY.

15. Hamzei L. (2011), The Competencies of Austrian Social Entrepreneurs: How Can They Be Approached in University Education?, Unpublished PhD thesis, Maastricht University, School of Business and Economics

16. Harding R. (2004), Social enterprise: The new economic engine?, "Business Strategy Review", Winter, pp. 40- 43.

17. Haugh H. (2006), Social enterprise: Beyond economic outcomes and individual returns, [in:] J. Mair, J. Robinson, K. Hockerts (eds.), Social entrepreneurship, UK: Palgrave Macmillan.

18. Hausner, J., Laurisz, N., Mazur, S. (2007), Przedsiębiorstwo społeczne konceptualizacja, [in:] J. Hausner (ed.), Zarzadzanie podmiotami ekonomii społecznej, MSAP UEK, Kraków.

19. Hoogendoorn B., Pennings E., Thurik R. (2010), What Do We Know About Social Entrepreneurship: An Analysis of Empirical Research, No. ERS-2009044-ORG, Erasmus Research Institute of Management (ERIM), pp. 1-39.

20. House R.J., Mitchell T.R. (1974), Path-goal theory of leadership, "Journal of Contemporary Business", Vol. 3, pp. 81-97.

21. Huybrechts B., Mertens S., Rijpens J. (2014), Explaining stakeholder involvement in social enterprise governance through resources and legitimacy, [in:] J. Defourny, L. Hulgård, V. Pestoff (eds.), Social Enterprise and the Third Sector: Changing European Landscapes in a Comparative Perspective, Routledge, pp. 157-175.

22. Kirby D.A. (2003), Entrepreneurship, McGraw Hill Education London.

23. Leadership in Social Enterprise (2014), Schwab Foundation for Social

The identification of skills and competencies

for effective management in social enterprises. A managerial perspective 
Entrepreneurship (online), http://www.schwabfound.org/sites/ default/files/file_uploads/leadership_in_social_enterprise_2014.pdf (accessed 3.5.2015).

24. Leś E. (2004), Przedsiębiorczość społeczna, "Nowe Życie Gospodarcze", No. 15.

25. Mair J., Martí I. (2006), Social entrepreneurship research: a source of explanation, prediction, and delight, "Journal of World Business", Vol. 41, No. 1, pp. 36-44.

26. Martin R., Osberg S. (2007), Social Entrepreneurship: The Case for Definition, "Stanford Social Innovation Review", Spring, pp. 34-41.

27. Mason Ch. (2012), Up for grabs: A critical discourse analysis of social entrepreneurship discourse in the United Kingdom, "Social Enterprise Journal", Vol. 8(2), pp. 123-140.

28. Miller T.L., Wesley C. L., Williams D.E. (2012), Educating the Minds of Caring Hearts: Comparing the Views of Practitioners and Educators on the Importance of Social Entrepreneurship Competencies, "Academy of Management Learning \& Education", Vol. 11, Issue 3, pp. 349-370.

29. Mort G., Weerawardena J., Carnegie K. (2003), Social entrepreneurship: towards conceptualisation, "International Journal of Nonprofit and Voluntary Sector Marketing", Vol. 8, No. 1, pp. 76-88.

30. Muscat E., Whitty M. (2009), Social Entrepreneurship: Values-Based Leadership to Transform Business Education and Society, "Business Renaissance Quarterly", Vol. 4(1), pp. 31-44.

31. Nicholls A. (2008), Playing the field: a new approach to the meaning of social entrepreneurship, "Social Enterprise Journal", Vol. 2, No. 1, pp. 1-5.

32. OECD (2003), The Non-profit Sector in a Changing Economy, Paris.

33. Parry K.W., Proctor-Thomson S.B. (2003), Leadership, culture and performance: The case of the New Zealand public sector, "Journal of Change Management", Vol. 3 (4), pp. 376-399.

34. Pearce J. (2003), Social Enterprise in Anytown, Calouste Gulbenkian Foundation, London.

35. Peredo A.M., McLean M. (2006), Social entrepreneurship: a critical review of the concept, "Journal of World Business, Vol. 41, No. 1, pp. 56-65.

36. Prabhu G.N. (1999), Social entrepreneurial leadership, "Career Development International", Vol. 4, No. 3, pp. 140-145.

37. Praszkier R., Nowak A. (2012), Przedsiębiorczość społeczna. Teoria i praktyka, Wolters Kluwer Polska, Warszawa.

38. Przedsiębiorczość społeczna - teoria i praktyka (2008), publikacja podsumowująca projekt "Akademia przedsiębiorczości. Rozwój alternatywnych form zatrudnienia" realizowanym $w$ ramach IW EQ UAL, Kraków.

39. Report on Social Entrepreneurship (2011), GEM Global Entrepreneurship 
Monitor, (online) www.gemconsortium.org/docs/376/gem-report-onsocial-entrepreneurship-executive-summary (accessed 3.5.2015).

40. Roberts D., Woods C. (2005), Changing the world on a shoestring: the concept of social entrepreneurship, "University of Auckland Business Review", Vol. 7, No. 1, pp. 45-51.

41. Sałustowicz P., (2007), Pojęcie, koncepcje i funkcje ekonomii społecznej, [in:] J. Starega-Piasek (ed.), Ekonomia społeczna. Perspektywa rynku pracy i pomocy społecznej, Warszawa, Instytut Rozwoju Służb Społecznych.

42. Schmid H. (2006), Leadership styles and leadership change in human and community service organizations, "Nonprofit Management and Leadership", Vol. 17, No. 2, pp. 179-194.

43. Sharir M., Lerner M. (2006), Gauging the success of social ventures initiated by individual social entrepreneurs, "Journal of World Business", No. 41 (1), pp. 6-20.

44. Shaw E., Carter S. (2007), Social entrepreneurship: theoretical antecedents and empirical analysis of entrepreneurial processes and outcomes, "Journal of Small Business and Enterprise Development", Vol. 14, No. 3, pp. 418-434.

45. Social Enterprise: A Strategy for Success (2002), DTI, (online),www.seeewiki. co.uk/ wiki/images/5 /5a/SE_Strategy_for_success.pdf, http://www. schwabfound.org/sites/default/files/file_uploads/ leadership_in_social_ enterprise_2014.pdf (accessed 3.5.2015).

46. Starnawska M. (2014), Zachowanie poprzez sieciowanie w przedsiębiorczości społecznej w odpowiedzi na trudne otoczenie instytucjonalne - przypadek 5 spółdzielni socjalnych, "Problemy Zarządzania", Vol. 12, No. 4, pp. 97-116.

47. Thach E., Thompson K.J. (2007), Trading places; Examining leadership competencies between for-profit vs. public and non-profit leaders, "Leadership and Organization Development Journal”, Vol. 28 (4), pp. 356-375.

48. Thompson J.L. (2002), The world of the social entrepreneur, "The International Journal of Public Sector Management", Vol. 15, No. 5, pp. 412-431.

49. Thompson J.L., Alvy G., Lees A. (2000), Social entrepreneurship - a new look at the people and the potential, Management Decision, Vol. 38, No. 5, pp. 328-338.

50. Thompson J.L., Doherty B. (2006), The diverse world of social enterprise: A collection of social enterprise stories, "International Journal of Social Economics", No. 33 (5/6), pp. 399-410.

51. Timmons J.A. (1999), New Venture Creation. Entrepreneurship for the 21st Century, Irwin/McGraw-Hill, Singapore.

52. Turner D., Martin S. (2005), Social entrepreneurship and social inclusion: building local capacity or delivering national priorities, "International Journal of Public Administration", Vol. 28, pp. 797-806.

53. Vroom V.H., Yetton P.W. (Eds) (1973), Leadership and Decision-Making, University of Pittsburgh Press, Pittsburgh, PA.

The identification of skills and competencies

for effective management in social enterprises. A managerial perspective 
54. Waddock S.A., Post J.E. (1991), Social entrepreneurs and catalytic change, "Public Administration Review", Vol. 51, pp. 393-407.

55. Wronka M. (2009), Identification of critical success factors of social enterprises research results, "Management", Vol. 13, No. 1, pp. 113-128.

56. Wronka-Pośpiech M., Frączkiewicz-Wronka A. (2014), The use of ICT for achieving the objectives of the business model - social enterprise perspective, "Polish Journal of Management", Vol. 10, No. 2, pp. 33-42.

57. Yujuico E. (2008), Connecting the dots in social entrepreneurship through the capabilities approach, "Socio-Economic Review", Vol. 6, No. 3, pp. 493-513.

58. Yunus M. (2008), Creating a world without poverty: Social business and the future of capitalism, New York: Public Affairs Books. 